Article

\title{
Making Sense of Emotions and Affective Investments in War: RT and the Syrian Conflict on YouTube
}

\author{
Precious N. Chatterje-Doody ${ }^{1, *}$ and Rhys Crilley ${ }^{2}$ \\ ${ }^{1}$ School of Arts, Languages and Culture, University of Manchester, Manchester, M13 9PL, UK; \\ E-Mail: precious.chatterje-doody@manchester.ac.uk \\ 2 Faculty of Arts and Social Sciences, The Open University, Milton Keynes, MK7 6AA, UK; E-Mail: rhys.crilley@open.ac.uk \\ * Corresponding author
}

Submitted: 14 December 2018 | Accepted: 19 March 2019 | Published: 9 August 2019

\begin{abstract}
Within the context of an 'affective turn' in media studies and the social sciences, this article explores the methodological challenges of researching emotions when studying online videos of conflict. Our study focuses on videos of the Syrian conflict shared on YouTube by the Russian state funded international broadcaster, RT. We propose that the concept of affective investment is a useful pivot between online videos of conflict and audience responses to them. Our study interrogates the role that affective investments play in 1) RT's YouTube representations of the Syrian conflict, and 2) audience comments on these videos. We draw attention to the important intersections of RT's representations of the conflict and audiences' affective investments in those representations, and draw attention to the methodological issues raised. Our empirical focus is two critical junctures in the Syrian conflict: the commencement of Russia's military intervention; and following the announcement of plans to withdraw Russian troops. We conclude by discussing the utility of affective investments in war when assessing online coverage of conflict, and suggesting avenues for further development.
\end{abstract}

\section{Keywords}

affective investments; conflict; emotion; international broadcaster; RT; Russia; social media; Syria; war; YouTube

\section{Issue}

This article is part of the issue 'Public Discussion in Russian Social Media', edited by Olessia Koltsova (Higher School of Economics, Russia) and Svetlana Bodrunova (St. Petersburg State University, Russia).

(C) 2019 by the authors; licensee Cogitatio (Lisbon, Portugal). This article is licensed under a Creative Commons Attribution 4.0 International License (CC BY).

\section{Introduction}

The affective turn in social sciences, media, and communication has seen increased engagement with the study of emotions (Ahmed, 2014; Clough \& Halley, 2007; Crawford, 2000; Gregg \& Seigworth, 2010; Harding \& Pribram, 2009; Lünenborg \& Maier, 2018; Massumi, 2015; Wetherell, 2012). In parallel, politicians, media pundits, and publics increasingly describe emotions as integral to the age of 'post truth' politics, or suggest that emotions and feelings have become more significant than rationality and facts in people's political decisionmaking (Crilley, 2018; Crilley \& Chatterje-Doody, 2018; Davies, 2018). Nevertheless, emotions have always been important in global politics, media and society: the novelty of the 'post-truth' age is the widespread recognition of this fact. Despite this, and despite the burgeoning literature on emotions and global politics (Åhäll, 2018; Åhäll \& Gregory, 2015; Bleiker \& Hutchison, 2008; Clément \& Sangar, 2018; Fierke, 2013; Hutchison, 2016; Ross, 2013), there remain difficulties in both understanding how exactly emotions matter, and in methodologically analysing them. In light of this, we suggest that the study of online content can reveal the dynamics by which emotions and affect shape people's understandings of global politics and society. We build on the concept of 'affective investments' (Solomon, 2014), proposing a methodology that links analysis of how war is represented on so- 
cial media with analysis of how audiences express emotions in response to these representations. Our focus is on YouTube videos of the Syrian conflict published by RT (formerly Russia Today) as well as 600 comments made on these videos by YouTube users.

How can social media content be studied in order to unpack the role of emotions in people's understandings of war? In order to answer this, we first outline the nascent literature on emotions, affect and war. We build upon the concept of 'affective investments' (Solomon, 2014) in media representations of war, outlining a methodology for studying affective investments in war on social media within both 1) the content of social media posts, and 2) comments made in response to these posts. Our methodology draws upon the study of discourse and emotions, and provides a three step framework of analysis for studying emotions and war on social media platforms. Our article provides two contributions: first, it proposes a framework for understanding how affective investments and war can be studied on social media, and proposes avenues for further development. Second, it provides empirical demonstration of the importance of affective investments in RT's media representation of the Syrian conflict.

\section{Theorising Affective Investments in War}

The unity implied by an affective turn (Clough \& Halley, 2007) masks 'diverse and thoroughly different conceptions and approaches' (Lünenborg \& Maier, 2018, p. 1) to the study of emotions across the social sciences. Scholars rarely agree on definitions of emotion and affect, or how to study them. Approaches range from the psychological, focused on biological expressions of emotion and affect using techniques developed in psychology and neuroscience; to the cultural, which view emotion not as something internal to the body but as 'social and cultural practices' (Ahmed, 2014, p. 9). Such cultural approaches have been simultaneously influential in the study of media and communication (Doveling, Von Scheve, \& Konijn, 2010; Lünenborg \& Maier, 2018; Wirth \& Schramm, 2005) and international politics and security (Åhäll, 2018; Åhäll \& Gregory, 2015; Bleiker \& Hutchison, 2008; Hutchison, 2016; Solomon, 2014; Steele, 2007). Synergizing and building upon these multidisciplinary foundations, we propose a method that scholars from diverse traditions can apply to study emotion on social media platforms in the context of war.

A cultural approach to emotion often refers to three interrelated terms. Affect is a bodily sensation that happens prior to and beyond consciousness (Clément \& Sangar, 2018, p. 5; Hutchison, 2016, p. 16); exemplified by hairs standing on end, crying, or a faster heartbeat. Emotions, in contrast, are intersubjective, culturally formed understandings and experiences of physiological change (Crawford, 2000, p. 125; Mercer, 2014, p. 516). Feelings, then, are the 'conscious awareness that one is experiencing an emotion' (Mercer, 2014, p. 516), and whilst one may internally attribute hairs standing on end as a feeling of fear, crying as sadness, or a faster heartbeat as excitement, the meaning attributed to them is culturally formed (Ahmed, 2014). Despite these distinctions, emotion and affect represent porous points along a continuum rather than binary categories (Ahmed, 2014, p. 207; Crawford, 2000; Hutchison \& Bleiker, 2014; Mercer, 2014), and we therefore draw both upon the concept of 'affective investments' (Solomon, 2014) and upon expressed understandings of emotion.

Sara Ahmed's work provides an avenue into studying emotions in media and communication. Her analysis is focused on 'reading texts that circulate in the public domain, which work by aligning subjects with collectives by attributing "others" as the "source" of our feelings' (Ahmed, 2014, p. 1). By studying media as texts and analysing how they represent emotions, scholars have provided a variety of insights into emotions and global politics by drawing upon interpretive methods, with discourse analysis being particularly prominent (Åhäll, 2018; Åhäll \& Gregory, 2015; Eroukhmanoff \& Fazendeiro, 2018; Hast, 2018; Hutchison \& Bleiker, 2014; Koschut, 2018; Ross, 2013; Van Rythoven, 2015; Solomon, 2012). Emma Hutchison offers a clear articulation of what this approach involves, arguing that emotions should be studied 'through representations, through the words and images in which emotions are expressed and in turn imbued with social meaning' (Hutchison, 2016, p. 18). Ultimately, representations are the closest one can get to apprehending emotions, because 'the internal, ephemeral nature of emotions precludes the possibility of understanding them through anything other than their instrumental display' (Hutchison, 2016, p. 18). Representations 'evoke feelings and affects, which in turn help to shape how one perceives of and belongs in the world' (Hutchison, 2016, p. 19). Representations therefore have social, political, and cultural significance, shaping how people think, feel, and act in the world.

To date however, there has been little progress in linking such emotive media representations with audiences' displays of emotion, in part because of the many methodological challenges for studying emotions, particularly in the context of war and conflict (Åhäll \& Gregory, 2015, pp. 229-231). Scholars interested in the intersections of media, communication, emotions, and war have drawn attention to the importance of 'emotive media' in conflict (Robinson, 2005, p. 344; see also Maltby \& Keeble, 2007; Zollman, 2017); theorized that war reporting that features 'emotive and graphic coverage' has greater influence over policymakers (Robinson, 2002, p. 25); studied how 'suffering is portrayed on screen and how the suffering is narrated' (Chouliaraki, 2008, p. 3; see also Sontag, 2003); and explored how lives are visually represented as grievable or not (Butler, 2009; Hutchison, 2016). Yet, whilst media representations of emotion are undoubtedly important, we contend that in the age of social media, so too is how audiences ex- 
press their emotions in online comments responding to media representations of war. Within this environment, media actors, host platforms and audiences (and the processes of interaction and circulation between them) all actively shape discourses, values and norms (Chatterje-Doody \& Crilley, 2019, p. 81; Poulsen, Kvale, \& Van Leeuwen, 2018). Thus, online comments produce interactions, commentary and framing which subsequent viewers also experience as they consume images of conflict online.

Our study fits within a tradition of research that is attuned to the study of media representations of war and audience interpretations of them (Gillespie, Gow, Hoskins, O'Loughlin, \& Žveržhanovski, 2010). We use the concept of 'affective investments' (Solomon, 2014) to inform a framework of analysis that enables us to explore how the content of social media posts is imbued with emotive content that provokes emotional responses from viewers. This approach is particularly helpful because, as the social theorist Ernesto Laclau notes, when studying media, scholars often focus on the 'form' of media, or what is represented through language and how this shapes identities and social action (Laclau, 2004, p. 326). Such analyses overlook the 'forces' of media discourse-the emotional and affective ways in which representations actually appeal to audiences (Laclau, 2007, p. 111). As Ty Solomon notes in his work that builds upon Laclau, 'words alone often cannot carry the power that they often have-the force of affect is needed to explain how words resonate with audiences and have political effects beyond their mere verbal utterance as such' (Solomon, 2014, p. 729). Consequently, media do not simply have political and social significance because of how they represent the world, but because of how audiences feel about what they represent; how they become affectively invested in the media representations that they read, view, and hear. According to Solomon, affective investments are:

Anchoring forces that bind subjects to their identities and particular kinds of discourses...affective investment is a key link between, on one hand, identities constructed in language [and media] and, on the other hand, the 'force' that imbues...identities with their potency and binding power. (Solomon, 2014, p. 729)

Such an understanding of affective investments has several implications for the study of emotions, media, global politics, and war. First, it suggests that the study of media and war should focus on how identities are represented and made potent through appeals to affect and emotion. Second, it implies that studies should address how audiences feel about the ways in which the world is represented to them. This is especially pertinent in the context of conflict, because, as Solomon's research demonstrates, the power of media does not solely lie in the verbal and visual expressions of media themselves, rather, these media 'are politically consequential precisely because they touch upon-or are felt by audiences to touch upon-a deeper nerve or 'essence' that such [media] are believed by audience members to express' (Solomon, 2014, p. 735). Thus, whilst we do not argue that media representations cause specific audience reactions, in stimulating audience views and interactions, online videos act as discursive nodes; points of reference for emotive engagement with the reported topic.

There are two important gaps within the literature on affective investments and war which can both be addressed by attention to online content. First, despite the shift in attention to 'audiences' affective investments' (Solomon, 2014, p. 720), studies undertaken so far provide limited engagement with what audiences actually think and feel about the media representations of war that they view. To date, scholarship on affective investments and war remains focused on feelings expressed by members of the public quoted in media articles (Solomon, 2012, 2014) or on interviews that do not account for the specific media which audiences may have engaged with (Holland, 2009). Second, studies of affective investments remain focused on traditional media, and do not account for the changes in the media ecology that followed the development of social media technologies that have had major implications for how war is both represented and waged (Hoskins \& O'Loughlin, 2010, 2015). Our article addresses these gaps by highlighting how social media is used to represent war in such a way that audiences not only feel affectively invested in the use of armed force, but that they can record their impressions for future audiences to experience together with the initial source. Furthermore, we propose a framework for studying how social media audiences express emotions in the comments they post on social media sites. Our framework builds upon scholarship on affective investments by drawing upon research on media and communication (Lünenborg \& Maier, 2018; Papacharissi, 2015), audience studies and conflict (Gillespie et al., 2010; O'Loughlin, 2011; Pears, 2016) as well as work focusing on the importance of social media comments as a data source for understanding war and security (Da Silva \& Crilley, 2017; Jackson, 2018; Shepherd \& Hamilton, 2016). This enables us to contribute to theorizing and empirically studying affective investments in media representations of war.

The study of affective investments in war is, however, fraught with methodological issues. Emotions are 'hard to operationalize, hard to measure, and hard to isolate from other factors' (Mercer, 1996, p. 1), and understanding their effects on politics and the legitimation of war is difficult. Even with the concept of affective investments providing a foundation for analysis we are still left with important questions. For example, how can we study and systematically analyse how media representations of war represent emotions? How can we understand what emotions audiences feel when they view media representations of war? And finally, how can we understand the link 
between the emotional content of media and the emotions felt by audiences? We now seek to address these questions by outlining a methodology for studying affective investments in war on social media sites.

\section{Studying Affective Investments in War on Social Media}

In order to understand how social media is used to represent war in such a way that its viewers feel affectively invested in the use of armed force, we propose a three-step method to integrate analysis both of the content of specific media; and of audience responses to it. Our empirical material is taken from the coverage of the Syrian conflict that the Russian state-backed international broadcaster, RT (formerly Russia Today) uploaded to YouTube. The Syrian conflict is important for understanding the contemporary dynamics of media representations of war and social media responses given that social media has been one of the primary ways in which people have found out news about the conflict (Lynch, Freelon, \& Aday, 2014; Powers \& O'Loughlin, 2015). What began as a revolutionary uprising against the Assad regime soon splintered into a violent civil war between competing factions including but not limited to the Assad regime, the National Coalition of Syrian Revolutionary and Opposition Forces, and various Salafi Jihadi groups such as ISIS and al Nusra (Lister, 2015). Over time, Syria transformed from 'a significant regional player into an arena in which a multitude of local and foreign players compete' (Hokayem, 2013, p. 11), and both traditional and social media have been integral to how actors involved in the Syrian conflict have sought to gain support for their cause. The Assad regime effectively prevented professional media reporting of the revolution by denying visas to international journalists and by targeting the lives of those who remained (Khamis, Gold, \& Vaughn, 2012). The Syrian Opposition subsequently used citizen journalists to communicate their message to foreign audiences in hopes of achieving regime change and their revolutionary goals (Crilley, 2017; Saleh, 2018). At the same time, state funded international broadcasters reported events in Syria in ways that aligned with the foreign policy interests of their home states (Matar, 2014, 2017; Salama, 2012). Whilst the USA and other 'Western' states favoured the Syrian Opposition (Geis \& Schlag, 2017), Russia preferred to preserve Bashar alAssad's control of Syria (Orttung \& Nelson, 2018; for an overview of international interests in Syria see Lynch, 2016, and Phillips, 2016).

For our theory-driven case construction (see Lai \& Roccu, 2019, p. 11) we focused on RT's YouTube videos on the Syrian conflict. For several reasons, these provide a valuable case for studying emotion and affect in digital visual representations of war, and audiences' responses to them. First, RT's outputs reflect 'the Russian government's official position...one way or another' (Putin, 2013), so its Syria reporting had to claim legitimacy for foreign policy decisions that audiences knew were widely condemned by the international community (Orttung \& Nelson, 2018, p. 3). The imperative to establish legitimacy is strongest during 'critical turning points' (ReusSmit, 2007, p. 44), so we honed down on two such junctures marking the start and end of Russian intervention. YouTube content was our specific focus, because international broadcasters' YouTube channels offer edited highlights that provide 'unique insight' into their brand identities and their attempts to set news agendas (al Nashmi, North, Bloom, \& Cleary, 2017, pp. 169-70); the platform itself is central to RT's dissemination strategy (al Nashmi et al., 2017; Orttung \& Nelson, 2018); and YouTube facilitates direct audience engagement via voting and commentary functions. For practical reasons, we restricted our analysis to the English-language international service. Though the vast majority of audience comments were made in English, we cannot accurately conclude their origin. Some bore hallmarks of non-native speakers (e.g., misuse of in/definite article); whilst others displayed perfect command of grammar and idiom.

\subsection{Data Collection}

We began by collecting data on RT's YouTube playlists about Syria. At the time of data collection, RT had 10 YouTube playlists of videos on Syria, only one of which RT continued to update with new videos (see Table 1).

Where other playlists focused on specific actors, places, or events, RT's 'Syrian conflict \& war against ISIS' provided an overview of RT's reports about the Syrian conflict from 2015 to the present day. We therefore analysed the 610 videos on this playlist in order to identify which videos reported the commencement of Russian intervention and the withdrawal of Russian forces from Syria. We found six videos explicitly reported the announcement of Russian intervention in Syria, and four reported the announcement that Russian forces would be withdrawn (see Table 2).

From these videos we selected two for our analysis: 'Russian military forces start airstrikes against ISIS in Syria' (RT, 2015); and 'BREAKING: Putin orders start of Russian military withdrawal from Syria' (RT, 2016). Both of these videos are breaking news reports marking critical junctures at which RT announces a change in Russian foreign policy in Syria. Thus, they provide insight into how RT claims legitimacy for Russian actions. Second, they both provoked a significant quantity of audience responses in terms of views, comments, upvotes and downvotes. Whilst RT's YouTube videos gain on average 66000 views and 1015 responses (Orttung \& Nelson, 2018, pp. 9-10), the first video we selected had over sixteen times the number of average views and seven times the responses of the average RT YouTube video. The second video had around three times as many views and responses as the average. These videos thereby provide a valuable source of comments to analyse the affective investments of the viewing audience. We analysed 
Table 1. RT playlists of videos on the Syrian conflict.

\begin{tabular}{lrl}
\hline Playlist Title & Number of videos & Dates of first and last video published \\
\hline Syrian conflict \& war against ISIS & 610 & 15 August 2015-still active \\
ISIS Uprising & 349 & 20 August 2014-23 October 2017 \\
Aleppo & 145 & 1 August 2016-6 March 2017 \\
Syria: Reports from the ground & 94 & 27 January 2014-18 December 2015 \\
RT reports from Syria & 86 & 26 October 2015-13 November 2017 \\
Russian Combat Cams & 33 & 30 September 2015-21 July 2016 \\
Russian warplane shot down at Syria-Turkey border & 32 & 24 November 2015-24 November 2016 \\
US missile strike against Syria & 24 & 6 April 2017-1 May 2017 \\
Russian Tu-154 plane crashes en route to Syria & 14 & 24 December 2016-28 December 2016 \\
RT crew under shelling, hit by anti-tank missile in Syria & 5 & 24 November 2015-28 November 2015 \\
\hline
\end{tabular}

Table 2. RT videos announcing Russian intervention (videos 1-6) and the withdrawal of Russian forces (videos 7-10).

\begin{tabular}{|c|c|c|c|c|c|c|c|}
\hline ID & Date & Title & Duration & Views & Comments & Upvotes & Downvotes \\
\hline 1 & $05 / 9 / 15$ & $\begin{array}{l}\text { Are you Syrious? 'Putin admits Russia's } \\
\text { aiding Syrian army in war'-western } \\
\text { media claim }\end{array}$ & $3: 39$ & 208179 & 1962 & 1400 & 191 \\
\hline 2 & $15 / 9 / 15$ & $\begin{array}{l}\text { 'We need to abandon double standards } \\
\text { to combat ISIS' - Putin }\end{array}$ & $3: 16$ & 100432 & 738 & 1200 & 61 \\
\hline 3 & $18 / 9 / 15$ & $\begin{array}{l}\text { Russia to consider sending troops to } \\
\text { Syria if requested }\end{array}$ & $1: 36$ & 19860 & 390 & 499 & 30 \\
\hline 4 & $30 / 9 / 15$ & $\begin{array}{l}\text { Russian parliament approves use of } \\
\text { military in Syria to fight ISIS }\end{array}$ & $14: 41$ & 76233 & 583 & 729 & 39 \\
\hline 5 & $30 / 9 / 15$ & $\begin{array}{l}\text { COMBAT CAM: First video of Russian } \\
\text { airstrikes on ISIS in Syria }\end{array}$ & $0: 50$ & 420682 & 1436 & 2000 & 132 \\
\hline 6 & $30 / 9 / 15$ & $\begin{array}{l}\text { Russian military forces start airstrikes } \\
\text { against ISIS in Syria }\end{array}$ & $13: 49$ & 1095221 & 2801 & 4100 & 342 \\
\hline 7 & $14 / 3 / 16$ & $\begin{array}{l}\text { BREAKING: Putin orders start of Russian } \\
\text { military withdrawal from Syria }\end{array}$ & $9: 30$ & 183345 & 2017 & 1600 & 140 \\
\hline 8 & $15 / 3 / 16$ & $\begin{array}{l}5 \text { years of war in Syria: Russia } \\
\text { withdraws its military forces from } \\
\text { Syria on conflict's anniversary }\end{array}$ & $1: 22$ & 21244 & 247 & 399 & 29 \\
\hline 9 & $15 / 3 / 16$ & $\begin{array}{l}\text { FIRST VIDEO: Russian warplanes } \\
\text { leaving airbase in Syria }\end{array}$ & $0: 39$ & 141444 & 383 & 554 & 57 \\
\hline 10 & $26 / 10 / 17$ & $\begin{array}{l}\text { Putin: } 90 \% \text { of Syria now liberated } \\
\text { from terrorists }\end{array}$ & $0: 57$ & 13927 & 321 & 595 & 15 \\
\hline
\end{tabular}

the entirety of the audio-visual information presented in these videos (RT, 2015, 2016) using a combination of techniques (see Section 3.2).

Next, we used a publicly available YouTube scraper to gather all comments on these videos, before extracting a manageable sample for analysis. To do so, we exported all comments to a spreadsheet, and sorted them by popularity. For each video, our sample consisted of the 100 most and 100 least popular comments, plus 100 selected randomly. This enabled us to look at audience affective investments that resonated more/less widely (indicated by popularity) and to balance this with the gen- eral picture. One potential limitation of the selection is that RT may have moderated or deleted the most negative comments. However, our working assumption was that the 'upvotes'/'downvotes' on comments present, and the videos' viewing figures would be reliable, given the extent of YouTube's efforts to tackle bots and spam (Keller, 2018; YouTube, 2012, 2018). Our inclusion of a random sample of comments was intended to further mitigate against this eventuality. Furthermore, our choice of manual analysis of these comments (see Section 3.3) allowed us to exercise critical judgment on a case-by-case basis. 


\subsection{Analysing Audiovisual Representations}

Automated sentiment analysis techniques can be applied to video content, however these are rarely geared to tripartite combinations of textual, visual and audio information, and have only limited capacity to take into account connections between discrete utterances (Poria, Cambria, Bajpai, \& Hussain, 2017, p. 874). This means that the overall narrative connections that define how wars and conflicts are presented can be lost. Consequently, we developed a manual methodology for our audio-visual analysis, which combined elements of Critical Discourse Analysis (CDA; Fairclough, 2010; Van Dijk, 2011) and its application to visual media (Bleiker, 2018; Gillespie \& Toynbee, 2006), as well as narrative analysis. These techniques were explicitly geared to uncovering relationships between knowledge and power; how supposedly objective facts are discursively constructed; and how the construction of stories about events and the actors involved in them can contribute to this process. Given that RT's coverage had to challenge dominant knowledge claims about the conflict, and that media texts work to 'construct acceptable knowledge' (Hansen, 2006, p. 8), we adapted Lene Hansen's (2006, pp. 73-83) three suggested foci for operationalising CDA: temporal moment/s; subject/s of discourse; and event/s. Two temporal moments were enshrined in our selection of reporting of 'critical junctures'. We therefore constructed two sets of research questions to establish how the 'facts' about identities and events in the Syrian conflict were discursively constructed via RT's YouTube videos:

RQ1: Which actors and events are represented as being important in the conflict? How (and using what normative assumptions) are they represented? How are relationships between actors characterised?

RQ2: What, if any, affective or emotional stimuli are involved in the representation of a) the actors involved; b) specific events; and c) the conflict as a whole?

We began by identifying all of the actors that the videos presented as being involved in the conflict. For each, we examined four aspects of the audio-visual stimuli used to represent them (see Table 3). These were the two forms of visual information (written text; still and moving images) and two forms of audio accompaniment (audio commentary; audio soundtracks). Where these were used to convey urgency or that something was unusual, we took this as a weak indicator of attempted affective stimulation. Where representations evoked a specific emotional orientation or conferred normative judgement (e.g., reference to an actor as legitimate/illegitimate), we took this as a strong indicator of attempted affective stimulation, following research that recognizes the interrelationship between emotions and normative judgements (Davies, 2018, p. 208; Schlag, 2018 , p. 219). We separately tallied these strong, weak and absent attempts at affective stimulation, and analysed the strong attempts further to determine the specific nature of the emotional claim. For example, visual imagery including explosions would be categorised as a strong attempt at affective stimulation, oriented towards an emotion of peril, threat or fear. We closely examined which normative judgements and analytical conclusions were explicitly ascribed to actors/actions, and which were embedded as if objective. This would include whether actors were referred to by their official names (e.g., 'government', indicating legitimacy) or using normatively-inscribed terms (e.g., 'regime', indicating illegitimacy).

We complemented our CDA with narrative analysis of how the development of the conflict was explicitly narrated within the videos and/or inferred by what was implied to have taken place off-screen (Crilley, 2015). We did this by applying a method of timeline reconstruction (Chatterje-Doody, 2014) in which an implied chronology is reconstructed through attention to the time pegs and links that are built into the telling of a particular story (even though the story need not be told in a chronological order). This approach preserves important information that is encoded through the overall integrated content of a (visual) text, including judgements about whether events merely happened subsequent to other events, or directly because of them; and about which actors' actions were consequential in which conflict developments. Such information is routinely lost in analytical methods that split the subjects of study into smaller segments or themes for analysis. Afterwards, we categorised each episode/event in the narrative according to the schema outlined in Table 3.

Table 3. Schema of affective and emotional representations.

\begin{tabular}{lllllll}
\hline & Written text & \multicolumn{2}{c}{ Visual images } & \multicolumn{2}{c}{ Audio commentary } & Audio soundtrack \\
\hline Affect (tally) & strong weak N/A strong weak N/A strong weak N/A strong weak N/A & & & \\
$\begin{array}{l}\text { Emotional } \\
\text { claim/normative } \\
\text { judgement } \\
\text { (+explicit/embedded) }\end{array}$ & & & & & & \\
\hline
\end{tabular}




\subsection{Analysing Audience Affective Investments}

Audience analysis is often based around measures of exposure to media content. However, such data cannot provide insights into audiences' feelings about the content that they consume. We must therefore consider how audiences actually act in response to images of war-for instance, when they choose to upload social media comments in response to media they view (Crilley, 2015, pp. 332-333; Hoskins \& O'Loughlin, 2010, p. 187). Whilst online commentators are not assumed to be representative of wider audiences, their comments remain discursive interventions, which reflect how media consumers make sense of contemporary world affairs (Ampofo, Collister, \& Chadwick, 2015; Da Silva \& Crilley, 2017), and can provide important evidence about the emotions that they express (Crilley \& Manor, 2018). Automated forms of sentiment analysis are useful for summarising the general reception that certain online content receives from its audiences (Poria et al., 2017). However, the contextual sparseness of social media comments can reduce the reliability of such methods, and they cannot assess audience reactions to specific aspects of how content is presented (including the representations embedded within it). We therefore chose manual analysis to bring together investigation both of media content and of audiences' feelings about that content, undertaking deep, qualitative engagement with the representations that conveyed emotion from source (media) to target (audience). We paid close attention to the kinds of representations that audiences chose to express their opinions of the viewed content, especially those conveying an emotional response.

We approached our coding and analysis inductively. Given that RT's videos served to claim legitimacy for Russia's intervention in Syria, we sought to ascertain how far RT's account of the conflict and its characterisation of actors resonated with audiences. We began by coding audience comments on the basis of the analytical claims that they implied, according to whether they supported, opposed, or expressed neutral/unclear views on Russian intervention. So as not to impose the conceptual framework of affective investments onto the empirical data, we coded the comments separately for emotion. Since emotions are complex and online comments can be brief and idiosyncratic, we kept our three coding categories for emotion broad. We focused on: positive emotions (including expressions of joy, excitement, respect, pride); negative emotions (including expressions of anger, sadness, disgust, confusion); and neutral or unclear emotions. Within this analysis of audience emotion, we took as indicators of emotion the use of normativelyloaded language and judgements; expressions of an extreme degree (e.g., use of superlatives); employment of either emojis (i.e., text faces) or acronyms for emotion (e.g., LOL); and the use of swearing.

\section{Affective Investment in the Syrian Conflict}

Our analysis revealed many affective and emotional stimuli within RT's coverage of the conflict in Syria. These were used primarily to express the legal and moral justifications for Russian intervention. They were embedded as the background to reporting, via casuallyingrained normative references to the different actors. On one side, referred to in formal language, were the 'Syrian government' that requested Russian assistance; the 'Damascenes' who supported it; the 'Russian parliament' that approved air strikes; the named senior politicians (especially President Putin) involved in decisive developments; and the UN Security Council, which gave its multilateral backing to peace resolutions ultimately facilitated by Russia. On the other side, couched in normative terms, were 'anti-government militants'; oppositional 'groups like Islamic State' (IS); 'terrorists'; 'foreign fighters'; Western politicians motivated by 'regime change'; and their military forces, whose interventions had increased chaos on the ground.

These emotive representations were packaged within a very clear narrative of the evolution of the conflict, which was layered through a combination of visual, textual and audio stimuli, many of which had overtly affective elements. These affective stimuli included dramatic red and black colour ways; visuals of fire, explosions and military hardware; and audio soundtracks featuring gunshots, explosions and mortar attacks. According to the narrative of the Syrian conflict that RT chose to portray in their YouTube videos, initial civil unrest spiralled out of control, creating a chaotic environment that allowed groups like IS to thrive. Motivated by regime change, Western powers intervened militarily, but this escalated tensions, and contributed to making IS a global threat. Russian armed intervention into this conflict situation came at the request of the legitimate Syrian government, and in response to the chaos on the ground. It was legally and morally legitimate; targeted; short in duration; and effective. At the withdrawal announcement in particular, the central role of Putin in achieving this 'successful' intervention was highlighted.

Our analysis of social media comments on these videos revealed that audiences largely accepted both RT's narrative of the conflict and its characterisations of the key actors involved. To be clear, this is not evidence that the videos caused such opinions, merely that they stimulated their expression as such. On the $300 \mathrm{com}-$ ments that we analysed on each of the two videos of breaking news in Syria, $71 \%(n=213)$ and $60 \%(n=179)$ respectively were supportive of the Russian intervention and/or suggested that it had been a success; $17 \%$ $(n=51)$ and $18 \%(n=56)$ were opposed to it and/or suggested that it had been a failure. Just $12 \%(n=36)$ and $22 \%(n=65)$ were neutral or expressed no clear sentiment towards the intervention. The main swing between the commencement and withdrawal announcements appears to be a slight reduction in support for the inter- 
vention, and increase in uncertainty/neutrality. This may be due to the wealth of alternative information available at the time of the withdrawal showing the situation not to be fully resolved. Nonetheless, negative comments at both points were similarly low.

Audiences of the two videos were much more likely to express an emotion of some kind in their commentary (81\% [ $n=244]$ and $77 \%$ [ $n=230]$ respectively), than to remain neutral or to express no emotion (19\% $[n=56]$ and $23 \%[n=70])$. Emotion-laden comments on the first video were almost evenly split between positive $(n=124)$ and negative $(n=120)$ emotions; whereas on the second video the balance was more towards positive $(n=144)$ rather than negative $(n=86)$ emotions. Yet, we have already established that this audience was overwhelmingly supportive of the intervention at both points. As it happens, the prevalence of emotional commentary from audiences was not related to their assessment of the intervention per se. Rather, it reflects the audience's affective investments (both positive and negative) in the identities represented within RT's coverage. The positive/negative split on the first video represented emotions expressed towards Russian actors; and towards oppositional 'terrorists'. As will be shown in detail below, the positively-weighted emotional responses to the second video ultimately reflected strong affective buy-in to the idea of a legitimate, effective and masculine Russian military.

Our qualitative analysis of audience comments revealed that the affective investments that audiences displayed strongly reflected RT's audio-visual representations of the Syrian conflict. Four key affective investments recurred: mistrust of global institutions (perceived within a conspiratorial framework); anger at US foreign policy; pride and gratitude towards Russia; and a heavily gendered understanding of Russia's intervention.

Table 4 exemplifies how audience comments on the videos replicate both RT's narrative of conflict developments and its characterisation of core actors. Significantly, however, it is via affective investments in core identities that commenters express their overall as- sessment of the conflict. These include negative sentiments about 'loser' NATO; the ineffective USA; and the 'terrorists' to be destroyed. Positive sentiments centre around the effective 'real men' of Russia, and particularly the personalised figure of 'Mr Putin'. Notably, as demonstrated in the final row, commentators frequently couched these identities specifically in terms of militarised masculinity, mapping gendered characteristics onto subjects and events at the moments of both commencement and withdrawal announcements.

Our article has proposed a new methodological toolkit to further the empirical study of affective investments in images of war-linking media sources to their audience. Our ensuing analysis of social media comments demonstrated that audiences were highly likely to express emotion in their responses to images of war, and that this emotion could be either positive or negative in nature. However, rather than being expressed in general terms as responses to the conflict itself, emotional engagements were closely linked to audiences' understandings of the actors involved in the conflict. Our empirical study indicates, therefore, that affective investment in the identities represented on-screen was a core component of the force with which the images of war were imbued. Neither video described the USA as homosexual and feminine, or Russia as a masculine 'real man'. Rather, this was how commenters expressed their feelings about the identities of the USA and Russia, and which bled into their assessments of the conflict. Individuals were affectively invested in the identity of a masculine, collective, effective, anti-terrorist Russia as opposed to a feminine, imperial, and out of control 'West' in Syria. Our analysis suggests that the concept of affective investment is crucial for helping to understand how audiences make sense of images of war, and how they relate to the audio-visual stimuli within which such conflict is represented.

\section{Conclusions}

In recent years, scholars have become increasingly aware of the importance of emotion and affect for understand-

Table 4. Examples of audience comments displaying affective investments in Russian military force in Syria.

\begin{tabular}{|c|c|c|}
\hline Affective Investment & Comments (Commencement) & Comments (Withdrawal) \\
\hline $\begin{array}{l}\text { Mistrust of global } \\
\text { institutions }\end{array}$ & NATO $=$ LOSER & $\begin{array}{l}\text { Nice move Mr Putin, keep the globalist } \\
\text { NWO trash guessing and confused... }\end{array}$ \\
\hline $\begin{array}{l}\text { Anger at US } \\
\text { foreign policy }\end{array}$ & $\begin{array}{l}\text { USA interference in Iraq created } \\
\text { Terrorists, while Russia interference } \\
\text { in Syria will end terrorism. }\end{array}$ & $\begin{array}{l}\text { Russia-bombs destroys the shit out of } \\
\text { terrorists and pulls out USA-bombs } \\
\text { people left and right, replace governments } \\
\text { and stay occupying countries for decades }\end{array}$ \\
\hline $\begin{array}{l}\text { Pride and gratitude } \\
\text { towards Russia }\end{array}$ & $\begin{array}{l}\text { Thank God for Putin. I don't even believe in } \\
\text { God, but it sure seems like he was sent by } \\
\text { a good force to stop this fucking insanity. }\end{array}$ & Great Job, Russia! \\
\hline $\begin{array}{l}\text { Gendered understanding } \\
\text { of Russia's intervention }\end{array}$ & $\begin{array}{l}\text { US gays can go home now to their } \\
\text { boyfriends, real men are taking over :) }\end{array}$ & $\begin{array}{l}\text { That's how you do it boys. Get in, } \\
\text { get the job done, get out. }\end{array}$ \\
\hline
\end{tabular}


ing world politics. Yet, there remain significant conceptual (Lünenborg \& Maier, 2018, p. 1) and methodological difficulties for studying emotions, particularly in the context of war and conflict (Åhäll \& Gregory, Chapter 17). These include the recurrent debates about whether emotions and politics should be studied as elite-led 'topdown' processes, or as being led from the 'bottom-up' direction of the individual (Delori, 2018; Schlag, 2018). Yet, how can we make any inferences about how audiences respond to images of war if we are not prepared to engage with both the content of those representations, and with audiences' reception of, and responses to them?

In this article, we have offered a way forward for investigating emotion and affect from media source to their audiences. Specifically, we have argued that one effective way to understand how audiences make sense of images of war is to engage directly with the reactions they express towards such images on social media. Social media comments are particularly instructive, since they represent audience members' direct engagement with the images they view. We cannot be sure of an actor's internal motivations, nor can we necessarily pick apart how an actor's emotional responses feed into their perceptions of what is a rational judgment (Mercer, 2006). Nonetheless, social media comments constitute an observable, empirical response to online content which can provide some insight into how such content is received (Van Dijck \& Poell, 2013).

Our approach to audience understandings of war is informed by the concept of 'affective investments' (Solomon, 2014), whereby media content stimulates emotional responses in its viewers by anchoring them to the identities and subjectivities it portrays. Our empirical analysis of breaking news videos and of audience reactions to them indicated that affective investments were crucial in how audiences interpreted and engaged with images of war. For, emotional responses to images of war were far more common than neutral ones. Yet, the character of such emotion did not necessarily correspond to the character of an audience's judgment about the overall nature of the conflict on display. It was not simply the images of war themselves that provoked an emotional reaction, but rather, the representations of the identities of the key actors involved with that conflict. These were related to how audiences assessed particular events.

It is becoming increasingly evident that images of war achieve their power amongst audiences as a direct result of the ways in which identities conveyed within images resonate with their audiences. Yet, to date there has been limited scholarly attention to bringing together empirical analysis of media representations of conflict, and audience responses to them-or to developing the methodological toolkit through which such a synergy may be made viable. With this preliminary study, we have provided some methodological suggestions for how the empirical study of affective investments in images of war-from media source to target audience-might be taken forward, and offered some foundations for future study of how links between media content and audience responses might be made.

\section{Acknowledgments}

The research upon which this article was based was conducted under the auspices of 'Reframing Russia for the Global Mediasphere: From Cold War to 'Information War'?', funded by the UK's Arts and Humanities Research Council, ref: AH/P00508X/1.

\section{Conflict of Interests}

The authors declare no conflict of interests.

\section{References}

Åhäll, L. (2018). Affect as methodology: Feminism and the politics of emotion. International Political Sociology, 12(1). https://doi.org/10.1093/ips/olx024

Åhäll, L., \& Gregory, T. (2015). Emotions, politics and war. Routledge.

Ahmed, S. (2014). Cultural politics of emotion. Edinburgh: Edinburgh University Press.

al Nashmi, E., North, M., Bloom, T., \& Cleary, J. (2017). Promoting a global brand: A study of international news organisations' YouTube channels. The Journal of International Communication, 23(2), 165-185.

Ampofo, L., Collister, S., \& Chadwick, A. (2015). Text mining and social media: When quantitative meets qualitative and software meets people. In P. Halfpenny \& R. Procter (Eds), Innovations in digital research methods (pp. 161-192). London: SAGE.

Bleiker, R. (Ed.). (2018). Visual global politics. New York, NY: Routledge.

Bleiker, R., \& Hutchison, E. (2008). Fear no more: Emotions and world politics. Review of International Studies, 34(S1), 115-135.

Butler, J. (2009). Frames of war: When is life grievable? London: Verso.

Chatterje-Doody, P. N. (2014). Harnessing history: Narratives, identity and perceptions of Russia's post-soviet role. Politics, 34(2), 126-137.

Chatterje-Doody, P. N., \& Crilley, R. (2019) Populism and contemporary global media: Populist communication logics and the co-construction of transnational identities. In F. Stengel, D. MacDonald, \& D. Nabers (Eds), Populism and world politics: Exploring interand transnational dimensions (pp. 73-99). London: Palgrave Macmillan.

Chouliaraki, L. (2008). The spectatorship of suffering. London: Sage.

Clément, M., \& Sangar, E. (Eds). (2018). Researching emotions in international relations: Methodological perspectives on the emotional turn. London: Palgrave Macmillan.

Clough, P. T., \& Halley, J. (Eds). (2007). The affective turn: 
Theorizing the social. Durham: Duke University Press.

Crawford, N. C. (2000). The passion of world politics: Propositions on emotion and emotional relationships. International Security, 24(4), 116-156.

Crilley, R. (2015). Seeing strategic narratives? Critical Studies on Security, 3(3), 331-333.

Crilley, R. (2017). Seeing Syria. Middle East Journal of Culture and Communication, 10(2/3), 133-158.

Crilley, R. (2018). International relations in the age of 'post-truth' politics. International Affairs, 94(2), 417-425.

Crilley, R., \& Chatterje-Doody, P. N. (2018). Security studies in the age of 'Post-Truth' politics: In defence of poststructuralism. Critical Studies on Security. Advance online publication. https://doi.org/10.1080/ 21624887.2018.1441634

Crilley, R., \& Manor, I. (2018). The aesthetics of violent extremist and counter-violent extremist communication. In C. Bjola \& J. Pamment (Eds), Countering online propaganda and extremism: The dark side of digital diplomacy (pp. 121-139). Abingdon: Routledge.

Da Silva, R., \& Crilley, R. (2017). 'Talk about terror in our back gardens': An analysis of online comments about British foreign fighters in Syria. Critical Studies on Terrorism, 10(1), 162-186.

Davies, W. (2018). Nervous states: How feeling took over the world. London: Jonathan Cape.

Delori, M. (2018). A plea for a discursive approach to emotions: The example of the French airmen's relation to violence. In M. Clément \& E. Sangar (Eds), Researching emotions in international relations: Methodological perspectives on the emotional turn (pp. 129-150). New York, NY: Palgrave Macmillan.

Doveling, K., Von Scheve, C., \& Konijn, E. A. (2010). The Routledge handbook of emotions and mass media. London: Routledge.

Eroukhmanoff, C., \& Fazendeiro, B. T. (2018). Emotions and time: Approaching emotions through a fusion of horizons. In M. Clément \& E. Sangar (Eds), Researching emotions in international relations: Methodological perspectives on the emotional turn (pp. 255-276). New York, NY: Palgrave Macmillan.

Fairclough, N. (2010). Critical discourse analysis: The critical study of language (2nd ed.). London: Routledge.

Fierke, K. M. (2013). Political self-sacrifice: Agency, body and emotion in international relations. Cambridge: Cambridge University Press.

Geis, A., \& Schlag, G. (2017). 'The facts cannot be denied': Legitimacy, war and the use of chemical weapons in Syria. Global Discourse, 7(2/3), 285-303.

Gillespie, M., \& Toynbee, J. (2006). Analysing media texts. Maidenhead: Open University Press.

Gillespie, M., Gow, J., Hoskins, A., O'Loughlin, B., \& Žveržhanovski, I. (2010) Shifting securities: News cultures, multicultural society and legitimacy. Ethnopolitics, 9(2), 239-253.

Gregg, M., \& Seigworth, G. J. (Eds). (2010). The affect the- ory reader. Durham, NC: Duke University Press.

Hast, S. (2018). Sounds of war: Aesthetics, emotions and Chechnya. Bristol: E-International Relations Publishing.

Hansen, L. (2006). Security as practice: Discourse analysis and the Bosnian war. New York, NY: Routledge.

Harding, J., \& Pribram, E. D. (Eds). (2009). Emotions: A cultural studies reader. New York, NY: Routledge.

Hokayem, E. (2013). Syria's uprising and the fracturing of the levant. London: Routledge.

Holland, J. (2009). From September 11th, 2001 to 9-11: From void to crisis. International Political Sociology, 3(3), 275-292.

Hoskins, A., \& O'Loughlin, B. (2010). War and media. Cambridge: Polity Press.

Hoskins, A., \& O'Loughlin, B. (2015) Arrested war: The third phase of mediatization. Information, Communication \& Society, 18(11), 1320-1338.

Hutchison, E. (2016). Affective communities in world politics. Cambridge: Cambridge University Press.

Hutchison, E., \& Bleiker, R. (2014). Theorizing emotions in world politics. International Theory, 6(3), 491-514.

Jackson, S. T. (2018). A turning IR landscape in a shifting media ecology: The state of IR literature on new media. International Studies Review. Retrieved from https://academic-oup-com.libezproxy.open.ac. uk/isr/advance-article/doi/10.1093/isr/viy046/ 5004645

Keller, M. H. (2018). The flourishing business of fake YouTube views. The New York Times. Retrieved from https://www.nytimes.com/interactive/2018/08/11/ technology/youtube-fake-view-sellers.html

Khamis, S., Gold, P. B., \& Vaughn, K. (2012) Beyond Egypt's "Facebook revolution" and Syria's "YouTube uprising:" Comparing political contexts, actors and communication strategies. Arab Media and Society, 15. Retrieved from https://www.arabmediasociety. com/beyond-egypts-facebook-revolution-and-syriasyoutube-uprising-comparing-political-contextsactors-and-communication-strategies/

Koschut, S. (2018) Speaking from the heart: Emotion discourse analysis in international relations. In M. Clément \& E. Sangar (Eds), Researching emotions in international relations: Methodological perspectives on the emotional turn (pp. 277-301). New York, NY: Palgrave Macmillan.

Laclau, E. (2004). Glimpsing the future. In S. Critchley \& O. Marchant (Eds.), Laclau: A critical reader (pp. 279-328). Abingdon: Routledge.

Laclau, E. (2007). On populist reason. New York, NY: Verso.

Lai, D., \& Roccu, R. (2019). Case study research and critical IR: The case for the extended case methodology. International Relations, 33(1). https://doi.org/ 10.1177\%2F0047117818818243

Lister, C. R. (2015). The Syrian Jihad: Al-Qaeda, the Islamic state and the evolution of an insurgency. Oxford: Oxford University Press. 
Lünenborg, M., \& Maier, T. (2018). The turn to affect and emotion in media studies. Media and Communication, 6(3), 1-4.

Lynch, M. (2016). The new Arab wars: Uprisings and anarchy in the Middle East. New York, NY: Public Affairs.

Lynch, M., Freelon, D., \& Aday, S. (2014). Syria's socially mediated civil war. United States Institute of Peace, 91(1), 1-35.

Maltby, S., \& Keeble, R. (2007). Communicating war: Memory, military and media. London: Arima Publishing.

Massumi, B. (2015). Politics of affect. London: John Wiley \& Sons.

Matar, D. (2014). A critical reflection on aesthetics and politics in the digital age. In A. Downey (Ed.), Uncommon grounds: New media and critical practices in North Africa and the Middle East (pp. 163-168). London: IB Tauris.

Matar, D. (2017). Introduction: Toward a sociology of communication and conflict: Iraq and Syria. Middle East Journal of Culture and Communication, 10(2/3), 99-108.

Mercer, J. (1996). Approaching emotion in international politics. Paper presented at International Studies Association Annual Meeting, San Diego, USA.

Mercer, J. (2006). Human nature and the first image: Emotion in international politics. Journal of International Relations and Development, 9(3), 288-303.

Mercer, J. (2014). Feeling like a state: Social emotion and identity. International Theory, 6(3), 515-535.

O'Loughlin, B. (2011). Images as weapons of war: Representation, mediation and interpretation. Review of International Studies, 37(1), 71-91.

Orttung, R. W., \& Nelson, E. (2018). Russia Today's strategy and effectiveness on YouTube. Post-Soviet Affairs, 35(2), 77-92.

Papacharissi, Z. (2015). Affective publics: Sentiment, technology, and politics. Oxford: Oxford University Press.

Pears, L. (2016). Ask the audience: Television, security and Homeland. Critical Studies on Terrorism, 9(1), 76-96.

Phillips, C. (2016). The battle for Syria: International rivalry in the new Middle East. New Haven, CT: Yale University Press.

Poria, S., Cambria, E., Bajpai, R., \& Hussain, A. (2017). A review of affective computing: From unimodal analysis to multimodal fusion. Information Fusion, 37, 98-125.

Poulsen, S. V., Kvale, G., \& Van Leeuwen, T. (2018). Special issue: Social media as semiotic technology. Social Semiotics, 28(5), 593-600.

Powers, S., \& O'Loughlin, B. (2015). The Syrian data glut: Rethinking the role of information in conflict. Media, War \& Conflict, 8(2), 172-180.

Putin, V. V. (2013) Visit to Russia Today television channel. Kremlin. Retrieved from http://en.kremlin.ru/ events/president/news/18319

Reus-Smit, C. (2007). International crises of legitimacy. International Politics, 44(2/3), 157-174.
Robinson, P. (2002). The CNN effect: The myth of news, foreign policy and intervention. London: Routledge.

Robinson, P. (2005). The CNN effect revisited. Critical Studies In Media Communication, 22(4), 344-349.

Ross, A. A. (2013). Mixed emotions: Beyond fear and hatred in international conflict. Chicago, IL: University of Chicago Press.

RT. (2015). Russian military forces start airstrikes against ISIS in Syria. YouTube. Retrieved from https://youtu. be/r11oHeV92nU.

RT. (2016). BREAKING: Putin orders start of Russian military withdrawal from Syria. YouTube. Retrieved from https://youtu.be/5rCwhYshgw8

Salama, V. (2012). Covering Syria. The International Journal of Press/Politics, 17(4), 516-526.

Saleh, L. (2018). Civic resilience during conflict: Syria's local councils. Journal of Arab \& Muslim Media Research, 11(2), 135-155.

Schlag, G. (2018). Moving images and the politics of pity: A multilevel approach to the interpretation of images and emotions. In M. Clément \& E. Sangar (Eds), Researching emotions in international relations: Methodological perspectives on the emotional turn (pp. 209-230). London: Palgrave Macmillan.

Shepherd, L. J., \& Hamilton, C. (Eds). (2016). Understanding popular culture and world politics in the digital age. London: Routledge.

Solomon, T. (2012). 'I wasn't angry, because I couldn't believe it was happening': Affect and discourse in responses to 9/11. Review of International Studies, 38(4), 907-928.

Solomon, T. (2014). The affective underpinnings of soft power. European Journal of International Relations, 20(3), 720-741.

Sontag, S. (2003). Regarding the pain of others. London: Macmillan.

Steele, B. J. (2007). Ontological security in international relations: Self-identity and the $I R$ state. London: Routledge.

Van Dijck, J., \& Poell, T. (2013). Understanding social media logic. Media and Communication, 1(1), 2-14.

Van Dijk, T. A. (2011). Discourse studies: A multidisciplinary introduction. London: SAGE.

Van Rythoven, E. (2015). Learning to feel, learning to fear? Emotions, imaginaries, and limits in the politics of securitization. Security Dialogue, 46(5), 458-475.

Wetherell, M. (2012). Affect and emotion. London: SAGE.

Wirth, W., \& Schramm, H. (2005). Media and emotions. Communication Research Trends, 24(3), 3-39.

YouTube. (2012). Views and 3rd party services. YouTube. Retrieved from https://youtube-creators. googleblog.com/2012/01/views-and-3rd-partyservices.html

YouTube. (2018). How video views are counted. YouTube. Retrieved from https://support.google.com/ youtube/answer/2991785?hl=en-GB

Zollman, F. (2017). Media, propaganda and the politics of intervention. London: Peter Lang. 


\section{About the Authors}

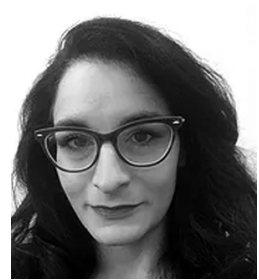

Precious N. Chatterje-Doody is a Post-Doctoral Research Associate at the University of Manchester, working on the AHRC-funded 'Reframing Russia' project. Her multidisciplinary research interests centre on questions of communication, perception, identity and security, with a particular focus on Russia. Her monographs on conspiracy theory and international broadcasting (with Dr. Ilya Yablokov, Leeds University) and on 'The Russian identity riddle: Unwrapping Russia's security policy,' are due to be published by Routledge in 2020. She tweets @PreciousChatD.

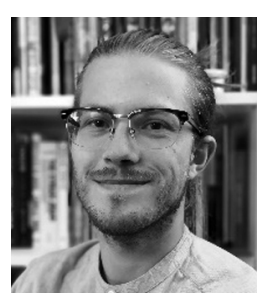

Rhys Crilley is a Post-Doctoral Research Associate in Global Media and Communication at The Open University, UK, where he works on the AHRC-funded 'Reframing Russia' project. His research explores the intersections of popular culture, social media and global politics with a specific interest in war and legitimacy. Rhys has published several journal articles and he is currently working on writing his first monograph on the legitimation of war on social media. He tweets at @rhyscrilley. 